\title{
Vegetative Propagation of Alberta magna by Tissue Culture and Grafting
}

J. Ben-Jaacov', A. Ackerman', and E. Ta1 ${ }^{2}$

Agricultural Research Organization, The Volcani Center, P. O. Box 6, Bet Dagan 50-250, Israel

\author{
G. Jacobs \\ Department of Horticultural Science, University of Stellenbosch, \\ Stellenbosch 7600, South Africa
}

Additional index words. in vitro propagation, pot plants, Rubiaceae

Alberta magna E.H. Mey (Rubiaceae), an attractive flowering evergreen species native to South Africa, is used as a small landscape tree and has potential as a flowering pot plant (Ben-Jaaeov et al., 1989). Propagation, either sexually or by cuttings, is difficult. Seed germination is poor and the seedlings have a long juvenile period. Cuttings taken from mature trees root poorly. We have developed an efficient method for the rapid vegetative propagation of mature-phase plants, in which mature-phase scion wood is grafted onto micropropagated juvenile plants.

A terminal stem segment $6 \mathrm{~mm}$ long was taken from a 10-mm-tall, 1-month-old seedling grown in a growth chamber maintained at $12 \mathrm{hr}$ each $25 / 17 \mathrm{C}$ (day/night). The seedling was subjected to a 12-hr photoperiod of $60 \mu \mathrm{mol} \cdot \mathrm{s}^{-1} \cdot \mathrm{m}^{-2}$ provided by cool-white fluorescent lamps. The leaves were removed, the shoot segment was surface sterilized in $1.5 \% \mathrm{NaOCI}$ for 15 rein, rinsed four times in sterile water, and placed on a filterpaper bridge in a test tube containing $10 \mathrm{ml}$ Anderson's liquid medium (Hartmann and Kester, 1983), pH 4.7, supplemented with $3 \%$ sucrose and $1 \mathrm{mg}$ benzyladenine (BA)/ liter. Axillary shoots proliferated rapidly and were subculture on half-strength MS medium solidified with $0.9 \%$ agar and containing $3 \%$ sucrose with or without BA at 1

Received for publication 20 Dec. 1989. Contribution from the Agricultural Research Organization, The Volcani Center. No. 2850-E, 1989 series. The cost of publishing this paper was defrayed in part by the payment of page charges. Under postal regulations, this paper therefore must be hereby marked advertisement solely to indicate this fact. 'Dept. of Ornamental Horticulture.

${ }^{2}$ Northern R\&D Project, Misgav Experimental Station, Misgav, Israel. $\mathrm{mg} \cdot \mathrm{liter}^{-1}$ (five test tube replications per treatment). After 8 weeks, explants on medium containing BA produced 34 shoots per culture, compared with seven in the absence of BA (Fig. 1A). Following completion of proliferation, individual, 6- to $10-\mathrm{mm}$-long shoots were subculture vertically for rooting on the same MS medium, but with BA replaced by either naphthaleneacetic acid (NAA) or indolebutyric acid (IBA) at 1 or 4 $\mathrm{mg} \cdot \operatorname{liter}^{-1}(10$ test tube replications per treatment). The control treatment was auxin-free. Shoots originating from medium without BA started rooting after 3 weeks, whereas those originating from BA medium rooted only after 8 weeks. However, no significant differences in the final rooting percentages and the numbers of roots per explant were observed between them. Rooting was significantly better with NAA than with IBA, and did not occur in auxin-free medium (Table 1). Plantlets were transferred to a sterilized peat-based potting medium in a humid greenhouse maintained at $26 \mathrm{C}$ day/16C night with daily irradiance of $400 \mu \mathrm{mol} \cdot \mathrm{s}^{-1} \cdot \mathrm{m}^{-2}$.

The micropropagated plants were transplanted in Mar. 1987 into 1.5-liter pots containing a medium of 3 volcanic ash :1 peat $(\mathrm{v} / \mathrm{v})$ and kept in a shade house with an irradiance of $1000 \mu \mathrm{mol} \cdot \mathrm{s}^{-1} \cdot \mathrm{m}^{-2}$. Plants were fertigated at every irrigation with $\left(\mathrm{mg} \cdot \mathrm{liter}^{-1}\right)$ 75 N, 35 P, 75 K. Nine months later (Dec. 1987), plants were $25 \mathrm{~cm}$ tall (Fig. 1B), and were transferred to a heated greenhouse (26C day/16C night) with irradiance of 1000 $\mu \mathrm{mol} \cdot \mathrm{s}^{-1} \cdot \mathrm{m}^{-2}$ ). After 15 days, they were wedge-grafted with matured scions of $A$. magna, one to three nodes long, obtained from Stellenbosch, South Africa. Leaves of the scions were removed and the grafts were tied with plastic ties (Hartmann and Kester, 1983) and covered with white plastic bags.
Table 1. Effects of IBA and NAA on in vitro rooting of A. magna (10 explants per treatment).

\begin{tabular}{lccc}
\hline \hline IBA & NAA \\
$\left(\mathrm{mg}^{\prime}\right.$ liter $\left.^{-1}\right)$ & $\begin{array}{c}\text { Rooting } \\
(\%)\end{array}$ & $\begin{array}{c}\text { Roots } \\
\text { per rooted } \\
\text { shoot } \\
(\text { no. })\end{array}$ \\
\hline 0 & 0 & 0 & $0.0 \mathrm{a}^{2}$ \\
1 & 0 & 10 & $1.5 \mathrm{a}$ \\
4 & 0 & 44 & $0.4 \mathrm{a}$ \\
0 & 1 & 67 & $4.7 \mathrm{~b}$ \\
o & 4 & 60 & $5.0 \mathrm{~b}$ \\
\hline
\end{tabular}

'Mean separation by Duncan's multiple range test, $P=0.05$.

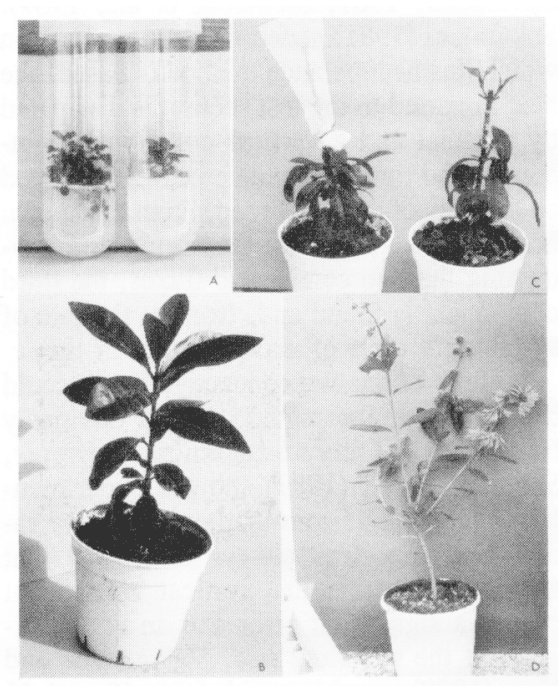

Fig. 1. Vegetative propagation of A. magna by tissue culture and grafting: (A) Shoot proliferation on half-strength MS medium: Left, BA at $1 \mathrm{mg} \cdot$ liter $^{-1}$; right, no BA. (B) Established tissue-cultured plant ready for grafting. (C) Juvenile,tissueculture-propagatedrootstockplants grafted with mature-phase scion wood. (D) Flowering plant 7 months after grafting.

The scions started to sprout and the plastic bags were removed 3 weeks later (Fig. IC). Ninety-three percent of the grafts were successful. Flowering started in summer, 7 months after grafting.

\section{Literature Cited}

Ben-Jaacov, J., A. Ackerman, and E. Tal. 1989. Development of new woody flowering pot plants-A comprehensive approach. Acts Hort. 252:51-58.

Hartmann, H.T. and D.E. Kester. 1983. Plant propagation, principles and practices. 4th ed. Prentice-Hall, Englewood Cliffs, N.J. 